\title{
PERBEDAAN TINGKAT RISIKO DEPRESI IBU HAMIL PRIMIGRAVIDA DAN MULTIGRAVIDA PADA TRIMESTER III USIA KEHAMILAN DI PUSKESMAS SIBELA SURAKARTA
}

Differences of depression risk between pregnant women primigravidae with women multigravida at pregnancy trimester III in Sibela Public Health Service of Surakarta

Sri Sayekti Heni Sunaryanti ${ }^{1}$ Sri Iswahyuni ${ }^{2}$ Prodi DIII Keperawatan STIKES Mamba'ul 'Ulum Surakarta (ss.heni.s29@gmail.com)

\begin{abstract}
ABSTRAK
Latar belakang: Masa menungu persalinan adalah yang sangat dapat mempengaruhi kondisi psikologi ibu, dimana ibu akan merasa khawatir dengan keadaan ibu maupun janin yang dikandungkannya. Salah satu kondisi yang dapat mengganggu dalam masa kehamilan adalah risiko depresi seperti stress. Timbulnya stress pada ibu hamil antara lain apakah akan memperoleh pertolongan dan perawatan semestinya, ancaman bahaya maut, keadaan sosial ekonomi, hubungan dengan suaminya, apakah bayinya cacat, ataukah bayinya akan meninggal. Apabila ibu hamil tidak mempersiapkan diri dengan baik dapat merugikan baik ibu hamil sendiri maupun janin yang dikandungnya.

Tujuan penelitian ini adalah mengetahui perbedaan tingkat risiko depresi ibu hamil primigravida dan multigravida pada trimester III usia kehamilan di Puskesmas Sibela Surakarta.

Metode Penelitian ini termasuk jenis penelitian studi komparatif. Desain penelitian yang digunakan adalah cross sectional. Sampel berjumlah 16 orang ibu hamil primigravida dan $16 \mathrm{ibu}$ hamil multigravida pada trimester III usia kehamilan. Alat analisis menggunakan uji comparative Mann Whitney U test.

Hasil penelitian menunjukkan Responden primigravida yang mengalami risiko depresi ringan 3 responden, 13 responden risiko depresi sedang, 8 Responden primigravida yang mengalami risiko depresi ringan dan 8 responden dengan risiko depresi sedang. Hasil uji statistik Mann Whitney U test menunjukkan Nilai mean rank risiko depresi responden Primigravida sebesar 21,66 sementara responden Multigravida sebesar 11,34 dengan nilai signifikansi sebesar 0,001, sehingga disimpulkan ada perbedaan tingkat risiko depresi ibu hamil primigravida dan multigravida pada trimester III usia kehamilan di Puskesmas Sibela Surakarta
\end{abstract}

Kata kunci : risiko depresi, primigravida, multigravida, trimester III kehamilan 


\begin{abstract}
Background: The waiting time for birthbaby was very influence for mother's psychological condition, where mother worried about maternal and fetal. One condition that could interfere in pregnancy is stressful. Some things that worry by pregnant women in face of impending labor, pain parturition time, whether to get help and proper treatment, the threat of danger of death, marital problems, socioeconomic situation, the relationship with her husband, whether disabled babies, or babies will die.

Objective : The result was to determine differences of depression risk between pregnant women primigravidae with women multigravida at pregnancy trimester 3 in Sibela Public Health Service of Surakarta

Methods: this research was a comparative research. Samples was 16 pregnant mother primigravidae and 16 pregnant mother multigravida at third trimester of pregnancy. Data obtained by measuring risk of depression. Data analysis was using Mann Whitney $U$ test

The results showed that 3 respondents primigravidae with mild depression risk 13 respondents with moderate depression risk, 8 Respondents primigravidae with mild depression risk and 8 respondents with moderate depression risk.. Result test of Mann Whitney $U$ test showed Mean rank of depression women primigravidae was 21,66, and depression women Multigravidae was 11,34, with significan p 0,001, the concussion there was differences of depression risk between pregnant women primigravidae with women multigravida at pregnancy trimester 3 in Sibela Public Health Service Of Surakarta.
\end{abstract}

Keywords: Depression Risk, primigravidae, multigravidae, 3rd trimester Pregnancy

\title{
PENDAHULUAN
}

Kehamilan merupakan peristiwa penting bagi seorang wanita. Kesehatan wanita sangat ditentukan oleh kesehatan jiwanya. Kondisi ini akan mendukung kesanggupannya untuk menyesuaikan diri selama proses kehamilan, persalinan dan menjadi ibu. Dalam kondisi ini, kehamilan merupakan periode yang penuh dengan tekanan emosional bagi beberapa wanita (Huliana, 2007).

Stress pada ibu hamil disebabkan oleh perubahan yang memerlukan penyesuaian. Banyak faktor yang menyebabkan seorang ibu hamil dapat terkena gangguan mental seperti depresi (Masbow, 2008).

Ada 9 dari 11 studi menemukan efek stress yang signifikan dalam kehamilan (prenatal stress) terhadap masa gestasi atau risiko kelahiran kurang bulan (Contrada,2011). Penelitian Aditya et al menyatakan hubungan derajat stress/depresi terhadap kelahiran prematur (Aditya et al, 2012)

Kehamilan adalah hasil dari pertemuan sperma dan sel telur. Dalam prosesnya, perjalanan sperma untuk menemui sel telur (ovum) betul-betul penuh perjuangan (Maulana, 2007). Kehamilan didefinisikan sebagai fertilisasi atau penyatuan dari spermatozoa dan ovum dan dilanjutkan dengan nidasi atau 
implantasi. Pertumbuhan dan perkembangan janin intra uterine mulai sejak konsepsi dan berakhir sampai permulaan persalinan (Hanafiah, 2008,).

Masa kehamilan dimulai dari konsepsi sampai lahirnya janin. Lamanya hamil normal adalah 280 hari (40 minggu atau 9 bulan 7 hari) dihitung dari hari pertama haid terakhir. Kehamilan dibagi dalam 3 triwulan, yaitu triwulan pertama dimulai dari konsepsi sampai 3 bulan, triwulan kedua dari bulan keempat sampai 6 bulan, triwulan ketiga dari bulan ke-7 sampai 9 bulan (Manuaba, 2010).

Primigravida adalah seorang wanita yang hamil untuk pertama kali, sedangkan multigravida adalah seorang wanita yang sudah pernah hamil 2 kali atau lebih. Menurut usia kehamilan, kehamilan dibagi menjadi: Kehamilan trimester pertama : 0 - 14 minggu, Kehamilan trimester kedua : 14 - 28 minggu, Kehamilan trimester ketiga : 28 - 42 minggu

Beberapa bulan terakhir kehamilan dapat menimbulkan keluhan baik fisik maupun mental. Janin yang semakin berkembang dan sudah mulai menempati posisi yang tepat membuat calon ibu merasa tidak nyaman. Trimester ketiga berlangsung sejak minggu ke 28 sampai persalinan (Manuaba, 2010).

Bertambahnya usia kehamilan akan menyebabkan perasaan yang tidak nyaman dan ingin segera melahirkan. Pada periode ini, kecemasan-kecemasan menghadapi persalinan akan muncul dan ulai dirasakan. Bayangan-bayangan negatif mulai menghantuinya, seperti apakah akan melahirkan normal? Bagaimana cara mengejan? Bagaimana jika terjadi sesuatu dengan dirinya pada saat melahirkan? Apakah bayinya akan lahir normal? (Huliana, 2007).

Latihan mental dilakukan dengan cara sikap relaksasi yang dapat dilakukan pada posisi tiduran, duduk bersandar latihan genderal relaksasi untuk persiapan mental dalam menghadapi proses persalinan. Tujuan persiapan mental adalah untuk menambah pengetahuan dan rasa percaya diri dalam menghadapi proses kehamilan dan persalinan, serta mengurangi rasa takut dan cemas (Haikal, 2007).

Dampak psikologi akibat tekanan emosional ibu selama kehamilan pada sistem keseimbangan endokrin dan penyesuaian diri setelah persalinan. Kesehatan psikososial wanita hamil sangat menentukan terhadap kesehatan ibu saat persalinan, bayi baru lahir dan nifas (Pieter ZH, 2010).

Berdasarkan uraian diatas, maka peneliti tertarik untuk mengetahui "Perbedaan Tingkat Risiko Depresi Ibu Hamil Primigravida dan Multigravida pada Timester III Usia Kehamilan Di Puskesmas Sibela Surakarta"

\section{METODE PENELITIAN}

Penelitian ini termasuk jenis penelitian studi komparatif dengan metode deskriptif yaitu metode penelitian yang dilakukan dengan tujuan utama untuk membuat gambaran perbandingan tentang suatu keadaan secara obyektif (Notoatmojo, 2012). Desain penelitian yang digunakan adalah cross sectional yaitu penelitian dengan melakukan pengukuran atau pengamatan pada saat bersamaan atau sekali waktu. (Aziz, 2008).

Penelitian dilakukan di wilayah kerja puskesmas Sibela Surakarta, dengan teknik accidental sampling didapatkan jumlah sampel sebanyak 32 (masingmasing sampel 16 untuk primigravida dan multigravida) 
Analisa data menggunakan uji non parametrik yaitu uji Mann Whitney U test dengan signifikansi $\leq 5 \%(\alpha \leq 0,05)$. (Sugiono, 2012).

\section{HASIL DAN PEMBAHASAN}

1. Analisis Univariat

a. Karakteristik Responden Berdasarkan Umur

Tabel 1. Distribusi frekuensi responden berdasarkan umur

\begin{tabular}{lcccc}
\hline \multirow{2}{*}{ Umur } & \multicolumn{2}{c}{ Primigravida } & \multicolumn{2}{c}{ Multigravida } \\
\cline { 2 - 5 } & Jumlah & Presentase (\%) & Jumlah & Presentase (\%) \\
\hline$<20$ tahun & 0 & 0 & 0 & 0 \\
20-35 tahun & 14 & 87,5 & 12 & 75,0 \\
$>35$ tahun & 2 & 12,5 & 4 & 25,0 \\
\hline Total & 16 & 100,0 & 16 & 100,0 \\
\hline
\end{tabular}

b. Karakteristik Responden Berdasarkan Pendidikan

Tabel 2. Distribusi frekuensi responden berdasarkan pendidikan

\begin{tabular}{ccccc}
\hline \multirow{2}{*}{ Pendidikan } & \multicolumn{2}{c}{ Primigravida } & \multicolumn{2}{c}{ Multigravida } \\
\cline { 2 - 5 } & Jumlah & Presentase (\%) & Jumlah & Presentase (\%) \\
\hline SMP & 4 & 25,0 & 7 & 43,8 \\
SMA & 9 & 56,3 & 8 & 50,0 \\
PT & 3 & 18,8 & 1 & 6,3 \\
\hline Total & 16 & 100,0 & 16 & 100,0 \\
\hline
\end{tabular}

c. Karakteristik Responden Berdasarkan Pekerjaan

Tabel 3. Distribusi frekuensi responden berdasarkan pekerjaan

\begin{tabular}{lcccc}
\hline \multirow{2}{*}{ Pekerjaan } & \multicolumn{2}{c}{ Primigravida } & \multicolumn{2}{c}{ Multigravida } \\
\cline { 2 - 5 } & Jumlah & Presentase (\%) & Jumlah & Presentase (\%) \\
\hline IRT & 13 & 81,3 & 11 & 68,8 \\
Swasta & 2 & 12,5 & 4 & 25,0 \\
Wiraswasta & 1 & 6,3 & 1 & 6,3 \\
\hline Total & 16 & 100,0 & 16 & 100,0 \\
\hline
\end{tabular}

d. Karakteristik Responden Berdasarkan risiko depresi

Tabel 4. Distribusi frekuensi responden antara primigravida dan responden multigravida menurut risiko depresi

\begin{tabular}{lrrrr}
\hline \multicolumn{1}{c}{ risiko depresi } & \multicolumn{2}{c}{ Primigravida } & \multicolumn{2}{c}{ Multigravida } \\
\cline { 2 - 5 } & \multicolumn{1}{c}{ Jumlah } & Presentase (\%) & Jumlah & Presentase (\%) \\
\hline Tidak depresi & 0 & 0 & 0 & 0 \\
Depresi ringan & 3 & 18,8 & 8 & 50,0 \\
Depresi sedang & 13 & 81,3 & 8 & 50,0 \\
Depresi berat & 0 & 0 & 0 & 0 \\
\hline Total & 16 & 100,0 & 16 & 100,0 \\
\hline
\end{tabular}


2. Analisis Bivariat

Hasil pengujian perbedaan risiko depresi antara ibu primigravida dengan ibu multigravida di Puskesmas Sibela Surakarta disajikan pada tabel 5.

Tabel 5. Hasil uji Mann-Whitney Test antara tingkat risiko depresi ibu hamil primigravida dan multigravida pada trimester III usia kehamilan

\begin{tabular}{lcccc}
\hline Variabel & Mean rank & $Z$ & p-value & Kesimpulan \\
\hline Primigravida & 21,66 & $-3,138$ & 0,001 & \multirow{2}{*}{ Ho ditolak } \\
Multigravida & 11,34 & & & \\
\hline
\end{tabular}

Berdasarkan hasil uji Mann-Whitney Test Nilai Z sebesar -3.138 dengan pvalue 0,001 . Oleh karena $p$-value $<0,05$, kesimpulan yang diambil adalah Ho ditolak, artinya ada perbedaan tingkat risiko depresi ibu hamil primigravida dan multigravida pada trimester III usia kehamilan di Puskesmas Sibela Surakarta.

a. Karakteristik Responden

1). Umur

Hasil penelitian ditinjau dari kelompok umur, umur antara 2035 tahun untuk responden primigravida terdapat 16 responden sementara 8 responden multigravida. Umur di atas 35 tahun menunjukkan banyak responden multigravida.

Sebagian besar masyarakat percaya bahwa bahwa usia yang tepat bagi seorang perempuan untuk melahirkan adalah pada usia 2030 tahun, dan hal ini mendukung bagi perawatan bayi oleh seorang ibu. Sedangkan kehamilan pada usia yang lebih awal atau remaja, atau pada usia lanjut telah diyakini akan meningkatkan risiko biomedik dan akan mengakibatkan pola tingkah laku yang tidak optimal, baik pada ibu maupun bayi yang dilahirkan (Manuaba, 2010). Bagi ibu yang masih muda dan belum mempunyai pengalaman sama sekali dalam hal merawat bayi berakibat timbulnya depresi, dimana responden merasa takut karena ketidak mampuannya melaksanakan tugas itu, atau kehilangan kepercayaan akan kemampuannya untuk membekali anak dengan kasih sayang dan perlindungan yang lazim.

2). Pendidikan

Hasil penelitian mengenai tingkat pendidikan menunjukkan responden primigravida lebih banyak berpendidikan SMA dan perguruan tinggi (PT). Menurut Notoadmodjo (2012) bahwa salah satu faktor yang berpengaruh pada perilaku kesehatan adalah tingkat pendidikan. Seseorang dengan tingkat pendidikan yang tinggi akan mempunyai kepedulian terhadap permasalahan kesehatan. Pengetahuan responden mengenai masalah persalinan dapat berasal dari tenaga kesehatan, majalah kesehatan, radio, yang pada akhirnya akan menambah pengetahuan responden dalam mempersiapkan diri menghadapi persalinan. Adanya pengetahuan yang baik menjadi modal agar responden dapat memperkecil terkena risiko depresi. 
3). Pekerjaan

Karanina (2005) menyatakan bahwa perempuan yang berpendidikan tinggi menghadapi tekanan sosial dan konflik peran, antara tuntutan sebagai perempuan yang memiliki dorongan untuk bekerja atau melakukan aktivitas lainnya di luar rumah, dengan peran mereka sebagai ibu rumah tangga dan orang tua dari anak-anak mereka. Dalam penelitian ini diperoleh data bahwa sebagian besar responden baik responden primigravida maupun multigravida adalah tidak bekerja. Dengan tidak bekerja adanya depresi yang terjadi pada responden adalah responden merasa akan kesulitan secara finansial dalam memenuhi kebutuhan bayinya mengingat responden tidak bekerja.

a. Analisis Univariat

1). Risiko depresi Primigravida

Berdasarkan hasil penelitian mengenai tingkat risiko depresi pada responden primigravida menunjukkan bahwa 3 respoden dengan risiko depresi ringan dan 13 dengan risiko depresi sedang. Banyaknya responden dengan risiko depresi sedang adalah responden baru pertama kali mengalami kehamilan.

Manuaba (2010) menyatakan bahwa wanita tidak mampu beradaptasi terhadap peran barunya sebagai seorang ibu maka akan timbul depresi setelah melahirkan (depresi postpartum) yang bervariasi dari hari kehari dengan menunjukkan kelelahan, mudah marah, gangguan nafsu makan, serta kehilangan hasrat untuk berhubungan seksual atau berhubungan intim dengan suaminya, sehingga akan mempengaruhi kepuasan seksualnya.

Beberapa penyesuaian perlu dilakukan oleh seorang wanita, baik dari segi fisik, maupun dari segi mental. Tuntutan sebagai ibu, akan dirasakan semakin berat karena kurangnya pengetahuan perempuan akan hal perawatan bayi, terutama pada perempuan yang baru pertama kali melahirkan (Primigravida). Sebagian wanita berhasil menyesuaikan diri dengan baik pada tuntutan peran dan situasi yang baru, tetapi ada sebagian wanita yang kurang dapat menyesuaikan diri, dan inilah yang jika tidak diperhatikan akan dapat menimbulkan gangguan-gangguan psikologis.

2). Risiko depresi Multigravida

Hasil penelitian menunjukkan risiko depresi responden multigravida memiliki jumlah yang sama yaitu masing-masing 8 responden. Fakor pencetus yang menjadikan tingginya risiko depresi sedang pada responden adalah faktor pengalaman. Berdasarkan hasil dari análisis jawaban kuesioner bahwa responden bahwa ketidakhadiran suami saat persalinan berlangsung meningkatkan rasa stress pada responden. Responden merasa tidak mendapat dukungan yang kuat dari angota keluarga khususnya suami. Peran 
suami dalam memberikan support sistem yang baik akan dapat memberikan dampak positif selama proses persalinan.

Hasil penelitian ini sejalan dengan peneitian yang dilakukan oleh Handayani (2015) yang menyatakan ada hubungan yang signifikan antara dukungan keluarga pada ibu dengan kecemasan ibu hamil trimester III

Zanden (2007) mengatakan bahwa menghadapi masa persalinan merupakan suatu kondisi konkrit yang mengancam diri ibu hamil yang menyebabkan perasaan tegang, khawatir, dan takut. Untuk itu, ibu hamil berusaha untuk dapat berhasil dalam menghadapi situasi tersebut sebaik-baiknya sampai masa persalinan tiba. Perubahan emosi tersebut tidak sama pada setiap wanita hamil. Perbedaan tersebut tergantung pada kepribadian individu, tipe stres yang pernah dialami, dan dukungan emosi yang didapat dari wanita tersebut.

b. Analisis Bivariat

Hasil penelitian menunjukan bahwa responden primigravida memiliki risiko depresi lebih tinggi dari pada responden multigravida. sebanyak 13 responden primigravida dengan risiko depresi sedang sementara responden multigravida hanya 8 orang. Hasil uji statistik menunjukkan $\mathrm{p}=0,001(\mathrm{p}<0,05)$, sehingga disimpulkan ada perbedaan tingkat risiko depresi ibu hamil primigravida dan multigravida pada trimester III usia kehamilan di Puskesmas Sibela Surakarta.

Yosep, (2010) menyatakan bahwa depresi adalah salah satu bentuk gangguan jiwa pada alam perasaaan (afektif, moood) yang ditandai kemurungan, kesedihan, kelesuan kehilangan gairah hidup, tidak ada semangat, dan merasa tidak berdaya, perasaan bersalah atau berdosa, tidak berguna dan putus asa. Bentuk gangguan postpartum yang umum adalah depresi, mudah marah dan terutama mudah frustasi serta emosional.

Manuaba (2010) menyatakan bahwa depresi postpartum biasanya terjadi pada 4 hari pertama masa setelah melahirkan dan berlangsung 1 2 minggu dengan gejala sebagai berikut, perasaan tidak berharga, mudah marah, kelelahan, insomnia, anorexia, sulit konsentrasi, melukai diri, anhedonia, menyalahkan diri, lemah dalam kehendak, tidak mau berhubungan dengan orang lain.

Primigravida adalah ibu postpartum yang melahirkan pertama kali. Usia seorang wanita pada waktu melahirkan anak pertama sangat berhubungan dengan umur dan riwayat depresi sebelumnya. Wanita yang terlalu muda melahirkan anak pertama mempunyai kemungkinan melahirkan anak dalam jangka waktu yang lebih panjang dan sering dihubungkan dengan risiko komplikasi kehamilan, kelahiran cacat, kematian ibu dan anak-anak, lebih tinggi kemungkinan untuk mengalami keracunan (toxemia), anemia dan penyakit-penyakit yang diakibatkan oleh kelahiran, disamping itu anak-anak mereka juga akan lebih besar kemungkinannya akan mengalami kematian setelah dilahirkan (neonatal) atau sewaktu masih bayi (Manuaba, 2010). 
Selain faktor umur, faktor lain yang mempengaruhi depresi yang lebih berat pada primigravida adalah faktor konstitusional, yaitu terjadinya gangguan postpartum berkaitan dengan status paritas dan terjadi lebih banyak pada wanita primigravida dan wanita primigravida lebih umum menderita blues.

Faktor lain yang penting dalam mempengaruhi depresi postpartum pada responden primigravida adalah faktor fisik. Gangguan emosional setelah melahirkan secara umum diakibatkan menurunnya kadar hormon secara tiba-tiba, dan biasanya terjadi dalam 3-5 hari setelah melahirkan dan mungkin dimulai pada hari pertama. Faktor lain adalah faktor sosial, mengemukakan bahwa pemukiman yang tidak memadai, lebih sering menimbulkan depresi pada ibu-ibu, selain kurangnya dukungan dalam perkawinan.

Kondisi riwayat masa lalu, yang mungkin mengalami penolakan dari orang tuanya atau orang tua yang overprotective, kecemasan yang tinggi terhadap perpisahan, dan ketidakpuasan dalam pernikahan (Karanina, 2005).

Selain adanya faktor risiko depresi yang terjadi pada ibu hamil, ibu hamil dapat juga mengalami risiko kecemasan pada kehamilan trimester III. Zanden (2007) mengatakan bahwa menghadapi masa persalinan merupakan suatu kondisi konkrit yang mengancam diri ibu hamil yang menyebabkan perasaan tegang, khawatir, dan takut. Untuk itu, ibu hamil berusaha untuk dapat berhasil dalam menghadapi situasi tersebut sebaikbaiknya sampai masa persalinan tiba. Adanya perubahan fisiologis yang menimbulkan ketidakstabilan kondisi psikologis selama hamil menumbuhkan kekhawatiran yang terus menerus dalam menghadapi kelahiran bayi pada wanita hamil pertama. Perasaan demikian akan terwujud dalam bentuk suatu kecemasan.

\section{SIMPULAN DAN SARAN}

\section{Simpulan}

Tingkat risiko ibu hamil primigravida di Puskesmas Sibela Surakarta banyak pada kategori depresi sedang sebesar 81,5\% sedangkan tingkat risiko ibu hamil multigravida antara depresi ringan dengan depresi sedang adalah sama yaitu 50\%. Terdapat perbedaan tingkat risiko depresi ibu hamil primigravida dan multigravida pada trimester III usia kehamilan di puskesmas Sibela Surakarta dengan nilai $\mathrm{p}=0,001$.

\section{Saran}

Perencanaan kehamilan sebaiknya dilaksanakan antara usia 20-35 tahun. Kontrol depresi secara mandiri dapat dilakukan dengan pernafasan yang baik, relaksasi, mengeluarkan keluhan pada suami/ keluarga, pendekatan agama, pendekatan keluarga dan senam hamil. 
Sebaiknya dilakukan promosi kesehatan tentang depresi pada ibu hamil. Pengkajian oleh tenaga kesehatan pada saat pemeriksaan ibu hamil trimester III hendaknya juga memfokuskan pada masalah psikologi.

Sebaiknya keluarga khususnya suami mampu memberikan dukungan pada ibu hamil trimester III, dengan dukungan keluarga terutama suami maka ibu mampu mengatasi masalahnya dnegan baik sampai proses persalinannya nanti.

\section{DAFTAR PUSTAKA}

Aditya R, Effendi JS, Hidayat T, Madjid TH. 2012. Hubungan Derajat Stress Psikologi Ibu Terhadap Kejadian Persalinan Kurang Bulan. Departemen Obstetri dan Ginekologi Fakultas Kedokteran Universitas Padjajaran RS Dr Hasan Sadikin. Indones J.2012:36(2):55-60

Admir, N. 2005. Depresi: Aspek Neurobiologi Diagnosis dam Tatalaksana. Jakarta. Balai Penerbit Fakultas Kedokteran Univesitas Indonesia

Azwar, S. 2012. Penyusunan Skala Psikologi . Yogyakarta: Pustaka Pelajar

Contrada JR. 2011. The Handbook of Stress Science, Biology, Psychology, and Health. United States of America: Bang Printing

Haikal, H. 2007. Hamil Sehat dengan Asupan Seimbang. www.wawasandigital.com. As Retrived on 5 Mei 2016.

Hanafiah. 2008. Buku Ajar Fisiologi Kedokteran. Jakarta: Penerbit buku kedokteran EGC.

Handayani,R. 2015. Faktor-faktor Yang Berhubungan Dengan Tingkat Kecemasan Menjelang Persalinan Pada Ibu Primigravida Trimester III di Wilayah Kerja Puskesmas Lubuk Buaya Padang Tahun 2012. Ners Jurnal Keperawatan. 11 (1): 62-71

Huliana, M. 2007. Panduan Menjalani Kehamilan Sehat. Jakarta: Puspa Swara

Karanina. 2005. Ilmu Penyakit Kandungan dan Keluarga Berencana Untuk Pendidikan Bidan, EGC, Jakarta: Rineka Cipta.

Manuaba, IBG. 2010. Gawat Darurat Obstetric Ginekologi \& Obstertric Ginekologi Sosial Untuk Profesi Bidan. Jakarta: EGC.

Masbow, 2008. Psikologi Abnormal. http:www.masbow.com/2008/10/depresi, Akses 26 Mei 2016.

Maulana, M. 2007. Cara Cerdas Menghadapi Kehamilan dan Mengasuh Bayi. Yogyakarta: Katahati.

Mochtar, R. 2012. Sinopsis Obstetri: Obstetri Fisiologi,Obstetri Patologi, edisi 2. Jakarta: EGC.

Notoatmodjo, S. 2012. Metodologi Penelitian Kesehatan. Jakarta: Rineka Cipta.

Pieter ZH, Lubis LN. 2010. Pengantar Psikologi Untuk Kebidanan. Jakarta : Kencana Perdana Media Group

Sugiono. 2012. Statistik Untuk Penelitian. Bandung: Andi Offset.

Yosep,I. 2010.Keperawatan Jiwa. Bandung: Refika Aditama.

Zanden, J.V; Crandell, T.L; Crandell, C.H., 2007. Human Development:Eight

Edition. New York: Mc. Graw - Hill International Edition. 